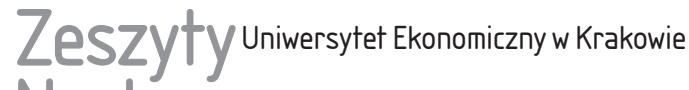 Naukowe
}

6(930)

ISSN 1898-6447

Zesz. Nauk. UEK, 2014; 6 (930): 87-100

DOI: 10.15678/ZNUEK.2014.0930.0606

\section{Elżbieta Bombińska}

Katedra Handlu Zagranicznego

Uniwersytet Ekonomiczny w Krakowie

\section{Możliwości wspierania eksportu w świetle międzynarodowych zobowiązań Polski}

\section{Streszczenie}

W artykule omówiono najważniejsze ograniczenia polityki proeksportowej Polski, które wynikają z jej zobowiązań podjętych na forum międzynarodowym. Przedstawione zostały zasady i narzędzia wspierania eksportu obowiązujące członków Światowej Organizacji Handlu, Organizacji Współpracy Gospodarczej i Rozwoju oraz Unii Europejskiej. Ograniczenie zakresu dostępnych dla Polski instrumentów polityki proeksportowej rodzi potrzebę doskonalenia dopuszczalnych narzędzi wspierania eksportu i poprawy efektywności ich wykorzystania.

Słowa kluczowe: polityka handlowa, eksport, liberalizacja handlu, Światowa Organizacja Handlu.

\section{Wprowadzenie}

Teoria ekonomii dowodzi, że internacjonalizacja gospodarki i jej uczestnictwo w międzynarodowym podziale pracy stanowią niezwykle istotne czynniki rozwoju gospodarczego kraju. Z tego względu rządy wielu państw podejmują aktywne działania zmierzające do intensyfikacji powiązań gospodarczych z zagranicą. Szczególne miejsce w tym zakresie zajmują działania ukierunkowane na wspieranie rozwoju eksportu, określane w literaturze mianem polityki proeksportowej kraju. 
Również w Polsce, dzięki przemianom ustrojowym po 1989 r., których skutkiem był m.in. wzrost stopnia otwartości gospodarki, zwiększyło się znaczenie powiązań z zagranicą w rozwoju gospodarczym kraju, a w konsekwencji - waga działań na rzecz wspierania eksportu. Otwieranie się polskiej gospodarki na świat w sferze instytucjonalnej było i jest związane z uczestniczeniem Polski w działalności wielu organizacji międzynarodowych oraz w regionalnych ugrupowaniach integracyjnych. Dzięki temu polscy eksporterzy uzyskali łatwiejszy dostęp do rynków zagranicznych. $\mathrm{Z}$ drugiej jednak strony członkostwo w organizacjach międzynarodowych oraz ugrupowaniach integracyjnych stało się źródłem licznych międzynarodowych zobowiązań Polski, dotyczących w szczególności zasad i form wspierania eksportu.

Celem artykułu jest prezentacja ograniczeń występujących w polskiej polityce proeksportowej - wykorzystywanych przez nią formach i dostępnym instrumentarium - będących konsekwencją zobowiązań podjętych przez nasz kraj na forum międzynarodowym. Opracowanie zostało podzielone na cztery części. W pierwszej z nich omówiono w skrócie istotę, przesłanki stosowania oraz główne narzędzia polityki proeksportowej. W kolejnych trzech rozdziałach natomiast scharakteryzowane zostały wybrane, najważniejsze zasady wspierania eksporterów, do których przestrzegania zobowiązane są kraje członkowskie Światowej Organizacji Handlu, Organizacji Współpracy Gospodarczej i Rozwoju oraz Unii Europejskiej.

\section{Istota, przesłanki i narzędzia polityki proeksportowej}

Polityka proeksportowa jest związana z oddziaływaniem rządu na sferę wymiany międzynarodowej. W literaturze przedmiotu na ogół wskazuje się na dwa sposoby rozumienia istoty tej polityki. W ujęciu węższym, nawiązującym do definicji polityki handlowej, można ją rozumieć jako zbiór reguł, metod i narzędzi stosowanych przez rząd w celu przyspieszenia rozwoju eksportu danego kraju. Tak postrzegana polityka proeksportowa stanowi rodzaj interwencjonizmu państwowego, którego celem jest wspieranie eksportu, wpływanie na jego rozmiary oraz strukturę towarową i geograficzną. W szerszym ujęciu natomiast polityka proeksportowa jest traktowana jako rodzaj polityki gospodarczej - polityki przyspieszania zrównoważonego rozwoju gospodarczego kraju za pomocą rozwoju eksportu.

W wąskim rozumieniu polityki proeksportowej uwaga jest więc skupiona na doraźnym zintensyfikowaniu eksportu, które daje krótkookresowy efekt w postaci wzrostu wywozu. Szeroko ujmowana polityka proeksportowa polega natomiast na podejmowaniu działań o charakterze strategicznym, przynoszących efekty w średnim i długim okresie, ukierunkowanych na dynamiczny, stały rozwój potencjału eksportowego gospodarki. W tym ujęciu eksponowane jest przyspie- 
szenie rozwoju gospodarczego, uzyskanie maksymalnych korzyści w ramach międzynarodowego podziału pracy. Szerokie rozumienie polityki proeksportowej jest zbieżne z zaproponowaną $\mathrm{w}$ ramach ekonomii rozwoju strategią gospodarki otwartej, w której ekspansja eksportowa jest postrzegana jako główna siła napędowa rozwoju gospodarki [Rosati 1990, s. 15-17].

Jako podstawowa przesłanka stosowania polityki proeksportowej wskazywana jest najczęściej niedoskonałość mechanizmu rynkowego w skali globalnej, związana z występowaniem różnorodnych zniekształceń na rynku światowym [Bhagwati 2003, s. 31]. Teoria zakłóceń, opracowana przez J. Bhagwatiego w latach 60. XX w., wyróżnia dwie podstawowe grupy zniekształceń (distortions) rynku: pierwszą tworzą zniekształcenia krajowe i międzynarodowe, drugą zaś zniekształcenia o charakterze ekonomicznym oraz pozaekonomicznym. Zgodnie z tą klasyfikacją zakłócenia konkurencji mogą występować zarówno na rynku krajowym, jak i światowym. Zniekształcenia rynku krajowego mogą być efektem polityki gospodarczej rządu danego kraju (w szczególności celno-podatkowej), mechanizmów funkcjonowania jego rynku wewnętrznego (wpływających np. na trudności w pozyskaniu kapitału na prowadzenie działalności gospodarczej czy w otrzymaniu należności), działania monopoli na rynku krajowym czy wysokiej inflacji. Z kolei źródłem zniekształceń międzynarodowych jest np. stosowana przez inne kraje polityka protekcjonistyczna, subwencjonowanie eksportu lub dumping. Obok wymienionych przyczyn zakłóceń mechanizmu rynkowego o charakterze ekonomicznym istnieją również zakłócenia wywołane czynnikami pozaekonomicznymi, do których należą np. sankcje i embarga, będące rezultatem decyzji politycznych poszczególnych państw lub ich grup.

Zniekształcenia rynku, niezależnie od rodzaju, wpływają na konkurencyjność eksporterów, utrudniając rozwój ich sprzedaży na rynkach zagranicznych. Analizując poszczególne rodzaje zakłóceń, należy podkreślić, że w przypadku tych, których źródłem są czynniki znajdujące się na poziomie krajowym, władza gospodarcza posiada możliwości ich eliminowania lub ograniczania negatywnych skutków dla krajowych eksporterów. Jeśli jednak źródłem zniekształceń jest polityka gospodarcza innych państw, szansa na skuteczne oddziaływanie pojedynczego kraju na zakłócenia mechanizmu rynkowego całej gospodarki światowej jest znikoma. W świetle teorii zakłóceń prowadzenie polityki proeksportowej jest uzasadnione, ponieważ zmierza ona do niwelowania wpływu poszczególnych zniekształceń na konkurencyjność eksporterów [Domiter 2008, s. 48 i nast.]. Teoria ta wyraźnie jednak podkreśla, że celem wspierania eksportu jest zapewnienie równych - nie zaś bardziej korzystnych - warunków funkcjonowania eksporterom krajowym względem podmiotów pochodzących z innych państw. Teoria zakłóceń dowodzi więc, że z uwagi na niedoskonałości mechanizmu rynkowego w sferze wymiany międzynarodowej prowadzenie aktywnej polityki proeksportowej staje 
się koniecznością, gdyż bez wsparcia własnego państwa eksporterzy krajowi są narażeni na dyskryminację na rynku światowym [Wziątek-Kubiak 1996, s. 43].

Polityka proeksportowa jest realizowana przez poszczególne kraje przez wykorzystanie różnorodnych narzędzi (tabela 1). Najogólniej można je podzielić na dwie podstawowe grupy [Gorynia 1996, s. 347-348]. Pierwszą stanowią instrumenty należące wyłącznie do polityki handlu zagranicznego: narzędzia polityki handlowej, walutowej, dewizowej. Drugą grupę tworzą natomiast narzędzia ogólnej polityki gospodarczej - w szczególności środki polityki podatkowej oraz polityki kredytowej - które są ustalane w specjalny (preferencyjny) sposób dla podmiotów biorących udział w wymianie handlowej z zagranicą. Są to np. ulgi w podatku dochodowym dla inwestycji proeksportowych, preferencyjne oprocentowanie kredytów, dogodniejsze warunki dostępu do gwarancji kredytowych dla eksporterów.

Polityka proeksportowa może mieć przy tym charakter systemowy, tzn. wyrażać się w popieraniu eksportu bez jakiejkolwiek dyskryminacji towarowej i podmiotowej, albo też może ona preferować wybrane branże, stając się tym samym tożsamą z polityką przemysłową [Bednarczyk 2000, s. 25].

Tabela 1. Klasyfikacja instrumentów polityki proeksportowej

\begin{tabular}{|l|l|l|}
\hline \multicolumn{2}{|c|}{ Narzędzia polityki proeksportowej } \\
\hline $\begin{array}{l}\text { Instrumenty ogólnej polityki } \\
\text { gospodarczej }\end{array}$ & $\begin{array}{l}\text { Narzędzia o charakterze sys- } \\
\text { temowym }\end{array}$ & $\begin{array}{l}\text { Instrumenty traktatowe } \\
\text { Instrumenty polityki handlu } \\
\text { zagranicznego }\end{array}$ \\
$\begin{array}{l}\text { Narzędzia stosowane selek- } \\
\text { tywnie }\end{array}$ & $\begin{array}{l}\text {-finansowe } \\
\text { Wsparcie informacyjno- } \\
\text {-promocyjne }\end{array}$ \\
\hline
\end{tabular}

Źródło: opracowanie własne.

W literaturze dość często można spotkać podział środków polityki proeksportowej na [Pierzchlewski 2011, s. 86]: działania traktatowe, instrumenty ekonomiczno-finansowe oraz wsparcie informacyjno-promocyjne (tabela 1).

Działania traktatowe są prowadzone przez najwyższe organy władzy państwowej i mają charakter strategiczny, kształtują warunki dostępu do zagranicznych rynków zbytu oraz oddziałują na podstawy i ramy prawne prowadzenia polityki handlu zagranicznego kraju. Można do nich zaliczyć: nawiązywanie stosunków politycznych i traktatowych na szczeblu rządowym, członkostwo w organizacjach międzynarodowych, podpisywanie umów handlowych, umów o tworzeniu ugrupowań integracyjnych (np. stref wolnego handlu), dzięki którym następuje eliminacja lub ograniczenie barier dostępu do rynków zagranicznych dla krajowych eksporterów itp. [Rębalski 2006, s. 184].

Instrumenty ekonomiczno-finansowe są uznawane za najważniejsze narzędzia polityki proeksportowej. W grupie tej można wymienić m.in.: kurs walutowy, 
subwencje, ulgi i ułatwienia o charakterze fiskalnym, ulgi i ułatwienia o charakterze kredytowym (np. preferencyjne kredyty eksportowe, wspieranie stóp procentowych kredytów eksportowych), gwarantowanie i ubezpieczanie kredytów i należności eksportowych z wykorzystaniem środków budżetowych [Bednarczyk 2000, s. 26-28].

Wsparcie promocyjno-informacyjne obejmuje z jednej strony działania mające na celu promocję makroekonomiczną, czyli kreowanie pozytywnego wizerunku kraju jako partnera gospodarczego, a także wspieranie promocji mikroekonomicznej realizowanej przez przedsiębiorstwa na rynkach zagranicznych (np. przez dofinansowywanie udziału w targach i wystawach za granicą lub kosztów projektów promocyjnych). Z drugiej strony zaś wspieranie eksporterów polega na dostarczaniu im możliwie pełnej informacji o warunkach działania na tych rynkach (np. przez gromadzenie i udostępnianie informacji na ten temat $\mathrm{w}$ formie publikacji, na portalach internetowych). Wsparcie promocyjno-informacyjne może być realizowane przez ministerstwa, banki centralne, placówki ekonomiczno-handlowe za granicą, specjalne agendy rządowe i instytucje tworzone, nadzorowane i finansowane przez państwo (np. izby handlowe, instytuty handlu zagranicznego).

\section{WTO}

Członkostwo w Światowej Organizacji Handlu (WTO) niesie dla jej członków, w tym w szczególności dla Polski, konieczność prowadzenia polityki wspierania eksportu zgodnej z zasadami wypracowanymi w tym zakresie na forum GATT/ WTO. Zasady te odnoszą się przede wszystkim do stosowania subsydiów eksportowych. Subsydia eksportowe to, najogólniej rzecz biorąc, świadczenia ze strony państwa na rzecz eksporterów, obniżające koszty produkcji, a w rezultacie poprawiające konkurencyjność towarów eksportowanych na rynku zagranicznym. Mogą one mieć charakter subsydiów bezpośrednich, czyli dopłat wypłacanych eksporterom w zależności od wielkości zrealizowanego przez nich eksportu, bądź też subsydiów pośrednich, trudniejszych do wykrycia, występujących np. w formie ułatwien fiskalnych lub ulg kredytowych dla eksporterów [Bożyk i in. 1998, s. 440-441].

System reguł dotyczących subsydiów eksportowych podlegał na forum GATT/ WTO długotrwałej ewolucji ${ }^{1}$, a jego obecny kształt - wobec fiaska rokowań rundy

\footnotetext{
${ }^{1} \mathrm{~W}$ pierwszych latach funkcjonowania GATT wymagane było jedynie dostarczenie informacji o zakresie i naturze subsydiowania, oszacowanie wpływu subsydiów na wymianę handlową oraz podanie warunków, które wywołały konieczność ich wprowadzenia. Żadna forma subsydiów nie była jednak zakazana. W 1955 r., zachowując możliwość stosowania subsydiów eksportowych dla tzw. produktów pierwotnych (primary products), do których zaliczono przede wszystkim
} 
Doha - wyznaczają dwa porozumienia wynegocjowane podczas rundy urugwajskiej: porozumienie w sprawie subsydiów i środków wyrównawczych (The Agreement on Subsidies and Countervailing Measures - SCM) oraz porozumienie o rolnictwie (The Agreement on Agriculture - AoA).

Porozumienie w sprawie subsydiów i środków wyrównawczych sprecyzowało definicję subsydiów i wprowadziło ich podział na trzy kategorie [Agreement... 2013]. Są to:

a) subsydia zabronione, tzw. czerwone - wywołują one zniekształcenia w handlu i ich stosowanie jest zakazane. W świetle SCM są nimi dwa rodzaje subsydiów, a mianowicie subsydia eksportowe (export subsidies) oraz subsydia związane z zawartością lokalnego składnika (local content subsidies). Subsydia eksportowe to formy wsparcia, które stanowią główny czynnik lub jeden z wielu czynników wpływających na wyniki uzyskiwane w eksporcie. Wykaz subsydiów eksportowych znalazł się w Aneksie I do porozumienia. Z kolei subsydia związane z zawartością lokalnego składnika to środki skłaniające krajowe podmioty do stosowania w produkcji składników krajowych zamiast importowanych;

b) subsydia dozwolone, ale z zastrzeżeniem możliwości podjęcia działań wyrównawczych (actionable) - jeśli partner handlowy udowodni, że wywołują one negatywne skutki w postaci poważnej szkody dla przemysłu kraju importującego lub nullifikacji bądź ograniczenia korzyści. Są to tzw. subsydia żółte;

c) subsydia dozwolone, bez możliwości podjęcia działań wyrównawczych (non-actionable), czyli tzw. subsydia zielone - zaliczono do nich m.in. subsydia na cele badawcze i rozwojowe oraz związane z ochroną środowiska. Ponieważ klauzula porozumienia, przewidująca zaistnienie poważnej szkody jako podstawy rozróżnienia subsydiów na actionable i non-actionable, została poddana przeglądowi po pięciu latach jej obowiązywania i w jego wyniku nie została przedłużona. Od 1 stycznia 2000 r. w regulacjach WTO występują jedynie dwa rodzaje subsydiów, tj. zakazane oraz dozwolone z możliwością podjęcia działań wyrównawczych.

Postanowienia drugiego z wymienionych porozumień rundy urugwajskiej Porozumienia o rolnictwie - objęły trzy filary polityki rolnej: dostęp do rynku krajowego, wsparcie krajowe oraz subsydia eksportowe. W odniesieniu do tych ostatnich nie zostały jednak wprowadzone - jak w przypadku artykułów przemysłowych - zakazy; celem porozumienia było jedynie ograniczenie zakresu

artykuły rolne, wprowadzono zakaz subsydiowania eksportu pozostałych produktów (non-primary products), który umożliwiał sprzedaż produktów na eksport po cenach niższych od cen płaconych za podobne produkty na rynku krajowym eksportera. Zakaz ten nie był jednak respektowany. W kodeksie subsydiów wynegocjowanym w ramach rundy tokijskiej (1973-1979) rozszerzono zakres stosowania subsydiów eksportowych na produkty przetworzone, jednak dopiero Porozumienie w sprawie subsydiów i środków wyrównawczych, wypracowane w trakcie rundy urugwajskiej, ustanowiło całkowity zakaz subsydiowania eksportu artykułów nierolniczych [Hajdukiewicz 2009, s. 64 i nast.]. 
subwencjonowania sprzedaży eksportowej artykułów rolnych, nie zaś jej całkowite wyeliminowanie. W harmonogramach liberalizacyjnych dla poszczególnych krajów określone zostały ilościowe i wartościowe poziomy ich zobowiązań (dotyczące zmniejszenia wydatków państwowych na subsydia eksportowe oraz ograniczenia wielkości subsydiowanego eksportu) - jedynie w przypadku przekroczenia uzgodnionych poziomów stosowanie subsydiów eksportowych zostało zabronione.

Porozumienie SCM i Porozumienie o rolnictwie miały poważne konsekwencje dla rozwoju multilateralnych uregulowań dotyczących subsydiowania, w tym subsydiowania eksportu. Porozumienia te objęły przede wszystkim wszystkie kraje członkowskie $\mathrm{WTO}^{2}$, w tym kraje rozwijające się oraz transformacji systemowej, jakkolwiek te dwie grupy państw uzyskały znaczące ulgi w ramach klauzul specjalnego i zróżnicowanego traktowania [Hajdukiewicz 2009, s. 68]. Jeżeli chodzi o politykę proeksportową, skutkiem tych porozumień jest całkowity zakaz subwencjonowania eksportu artykułów przemysłowych oraz możliwość stosowania subwencji eksportowych jedynie w odniesieniu do artykułów rolnych. Propozycja całkowitego wyeliminowania subsydiów eksportowych do 2013 r., która pojawiła się w czasie rundy Doha, wobec braku porozumienia prowadzonych w jej ramach negocjacji nie weszła w życie ${ }^{3}$.

\section{OECD}

Jak już wspomniano, jednym z narzędzi polityki proeksportowej jest wspieranie kredytów eksportowych przez rząd kraju eksportera. Wsparcie to umożliwia eksporterom sprzedaż towarów i usług na warunkach kredytowych, których bardzo często nie są oni w stanie zaoferować zagranicznym nabywcom samodzielnie, bez pomocy państwa. Wspieranie kredytów eksportowych może przy tym przybierać nie tylko formę wąsko rozumianego finansowania eksportu w postaci preferencyjnych kredytów eksportowych czy wspierania stóp procentowych takich kredytów ${ }^{4}$. W praktyce polega ono bardzo często na ubezpieczaniu i gwarantowaniu kredytów eksportowych z udziałem środków budżetowych, a ponadto może występować w postaci finansowania pomocowego (tabela 2).

${ }^{2}$ Wcześniej jedynie kraje rozwinięte przyjęły zakaz stosowania subsydiów w eksporcie artykułów przemysłowych.

${ }^{3}$ Szerokie omówienie przebiegu tych negocjacji znaleźć można w [Hajdukiewicz 2012, s. 45-60].

${ }^{4}$ Wspieranie stóp procentowych polega na tym, że banki komercyjne udzielające kredytów eksporterom odraczającym płatności eksportowe lub zagranicznym nabywcom towarów eksportowanych otrzymują z budżetu państwa środki finansowe, które umożliwiają im ustalenie oprocentowania takich kredytów na poziomie niższym od rynkowego. 
Tabela 2. Formy wspierania kredytów eksportowych

\begin{tabular}{|l|l|l|l|}
\hline \multicolumn{4}{|c|}{ Formy wspierania kredytów eksportowych } \\
\hline $\begin{array}{l}\text { Finansowanie eks- } \\
\text { portu: }\end{array}$ & $\begin{array}{l}\text { Ubezpieczanie kredy- } \\
\text { - preferencyjne kre- } \\
\text { tyty eksportowe } \\
\begin{array}{l}\text { z udziałem środków } \\
\text { centoranie stóp pro- } \\
\text { budżetowych } \\
\text { eksportowych kredytów }\end{array}\end{array}$ & $\begin{array}{l}\text { Gwantowanie kredy- } \\
\text { tów eksportowych } \\
\text { z udziałem środków } \\
\text { budżetowych }\end{array}$ & $\begin{array}{l}\text { Finansowanie pomo- } \\
\text { cowe (tied aid) }\end{array}$ \\
\hline
\end{tabular}

Źródło: opracowanie własne.

W okresie powojennym uwidoczniła się tendencja, zwłaszcza w grupie państw wysoko rozwiniętych, do intensywnego wykorzystywania finansowych instrumentów wspierania eksportu w kreowaniu przewagi konkurencyjnej krajowych eksporterów. Zjawisko to wypaczało ideę wolnej konkurencji na rynku międzynarodowym, której podstawą powinny być jakość i cena eksportowanych dóbr i usług, nie zaś korzystniejsze warunki wsparcia finansowego eksporterów przez rządy poszczególnych krajów. W celu przeciwdziałania zjawisku tej swoistej „wojny kredytowej” podjęto próby dalszego ${ }^{5}$ wypracowywania i ujednolicenia zasad wspierania kredytów eksportowych.

Organizacją, na forum której działania podejmowane w tym zakresie miały i mają szczególnie istotny wpływ na kształt polskiej polityki proeksportowej, jest Organizacja Współpracy Gospodarczej i Rozwoju (OECD), której członkiem Polska została w 1996 r. Wsparcie kredytów eksportowych stosowane przez kraje członkowskie tej organizacji odbywa się zgodnie z zasadami ujętymi w dokumencie OECD: Porozumienie w sprawie oficjalnie wspieranych kredytów eksportowych (Arrangement on Officially Supported Export Credits), nazwanym Konsensusem OECD. Został on zawarty w 1976 r., w życie wszedł dwa lata później i był kilkakrotnie modyfikowany; podpisały go wszystkie kraje członkowskie OECD z wyjątkiem Islandii, Turcji i Meksyku. Konsensus ustanowił ramy dla wspierania kredytów eksportowych udzielanego przez kraje członkowskie organizacji. Przyjęcie wspólnych zasad w tym zakresie ma na celu uniemożliwienie konkurowania przez warunki finansowania, które są oferowane importerom.

\footnotetext{
${ }^{5}$ Pierwsze próby opracowania i harmonizacji zasad kredytowania i ubezpieczania transakcji eksportowych podjęto już w latach 20. i 30. XX w. Między innymi w tym celu w 1924 r. utworzono - zrzeszający prywatnych ubezpieczycieli - Międzynarodowy Związek Ubezpieczeń Kredytów (International Credit Insurance Assaciation - ICIA), zaś 10 lat później powołano do życia Międzynarodową Unię Ubezpieczycieli Kredytu i Inwestycji (International Union of Credit and Investment Insurers), tzw. Unię Berneńską, która zrzesza ubezpieczycieli państwowych [Michalik 2009, s. 110-111].
} 
W Konsensusie OECD określono graniczne, czyli najbardziej korzystne parametry kredytów eksportowych objętych oficjalnym wsparciem, takie jak:

- minimalna płatność zaliczkowa wpłacana przez importera, która musi stanowić co najmniej 15\% wartości kontraktu;

- maksymalny okres spłaty kredytu, który uzależniono od poziomu rozwoju gospodarczego państw kredytobiorców; okres ten nie może być krótszy niż dwa lata i może wynosić maksymalnie 8,5 roku (w przypadku eksportu kierowanego do krajów bogatych, należących do tzw. kategorii I - w zależności od DNB) albo 10 lat (w przypadku eksportu kierowanego do krajów biedniejszych z tzw. kategorii II);

- minimalne oprocentowanie - w porozumieniu ustalono minimalne referencyjne stopy oprocentowania kredytów eksportowych, tzw. CIRR-y (Commercial Interest Reference Rates), poniżej których zobowiązano się nie udzielać kredytów eksportowych. Od 1995 r. stopy te są ustalane przez Sekretariat OECD odrębnie dla każdej waluty kontraktu na okres 1 miesiąca.

Z zasad Konsensusu OECD wyłączone zostały warunki kredytowania eksportu niektórych grup towarowych ${ }^{6}$, takich jak: sprzęt wojskowy, statki morskie, elektrownie jądrowe, samoloty, artykuły rolne, a także projekty z zakresu energetyki odnawialnej i wielkie projekty inwestycyjne (project finance). Odrębne zasady ustanowiono również w odniesieniu do kredytów udzielanych na zasadzie pomocy wiązanej (tied aid $)^{7}$. Są one przyznawane na zasadach preferencyjnych, a mogą z nich korzystać wyłącznie wybrane kraje rozwijające się, znajdujące się na liście publikowanej przez $\mathrm{OECD}^{8}$. Warunki finansowe kredytu w ramach pomocy wiązanej (tj. termin spłaty, oprocentowanie, karencja) są ustalone w taki sposób, aby zapewnić co najmniej 35-procentowy poziom dotowania. Przedsięwzięcia finansowane w ramach pomocy wiązanej to projekty, które nie wykazują zdolności do samofinansowania się lub nie znajdują finansowania komercyjnego; najczęściej dotyczą one ochrony środowiska, zdrowia, poprawy bezpieczeństwa pracy, warunków bytowych ludności, edukacji.

\section{Unia Europejska}

Akcesja Polski do UE oznaczała - w obszarze wymiany handlowej z zagranicą - przyjęcie jednolitych zasad dotyczących wspólnej polityki handlowej, a w szcze-

${ }^{6}$ Stały się one przedmiotem odrębnych porozumień w ramach OECD.

${ }^{7}$ Obok konsensusu wynikają one również z innych dokumentów OECD, takich jak: Ex Ante Guidance for Tied Aid, DAC Principles for Project Appraisal, DAC Guidelines on Aid and Environment, Good Practices for Environmental Impact Assessment of Development Projects.

${ }^{8} \mathrm{~W}$ tej grupie państw znajdują się m.in. Gruzja, Chiny, Mołdowa, Wietnam, Indonezja, Filipiny, Bangladesz, Czarnogóra, Serbia, Ghana czy Angola. 
gólności zasad polityki eksportowej. Polityka eksportowa UE obejmuje z jednej strony ochronę rynku wewnętrznego Wspólnoty, z drugiej zaś - co stanowi przedmiot niniejszego opracowania - jej celem jest wsparcie rozwoju eksportu państw członkowskich. Środki ochronne w wywozie są ustanawiane na szczeblu wspólnotowym. Są one stosowane w uzasadnionych przypadkach ${ }^{9}$ i mogą przyjąć formę zakazu eksportu, pozwoleń wywozu albo nadzoru statystycznego. Srodki te proponuje Komisja Europejska, zaś Rada UE przyjmuje je kwalifikowaną większością głosów ${ }^{10}$. W zakresie polityki proeksportowej natomiast podział kompetencji jest nieco inny, gdyż jest ona prowadzona zarówno na szczeblu wspólnotowym, jak i na poziomie krajowym.

Biorąc pod uwagę omówiony wcześniej podział narzędzi polityki proeksportowej na instrumenty traktatowe, ekonomiczno-finansowe oraz wsparcie promocyjno-informacyjne, można stwierdzić, że w zakresie instrumentów traktatowych Wspólnota posiada wyłączne kompetencje. Wyrażają się one, zgodnie z art. 133 Traktatu ustanawiającego Wspólnotę Europejską, w kształtowaniu przez instytucje wspólnotowe relacji handlowych z krajami trzecimi oraz organizacjami gospodarczymi ${ }^{11}$, a także we wspólnym reprezentowaniu przez te instytucje interesów państw członkowskich w rokowaniach handlowych na forum międzynarodowym [Barcz, Kawecka-Wyrzykowska i Michałowska-Gorywoda 2007, s. 205].

Ponadto w działaniach podejmowanych na poziomie wspólnotowym na rzecz wspierania unijnego eksportu szczególne znaczenie ma ochrona interesów europejskich eksporterów. Rada Unii Europejskiej w specjalnym rozporządzeniu o wspólnej polityce handlowej ${ }^{12}$ upoważniła Komisję Europejską do podejmowania działań w celu usuwania przeszkód stwarzanych przedsiębiorcom euro-

${ }^{9}$ Są nimi np. zapobieganie niekontrolowanemu wywozowi dóbr rzadkich (np. dóbr kultury); ochrona wynikająca z zasad moralności, ochrony zdrowia i życia ludzi, zwierząt i roślin; zapewnienie bezpieczeństwa międzynarodowego, ochrona własności przemysłowej i handlowej; przeciwdziałanie nieprzewidzianym praktykom oraz ochrona interesu Wspólnoty. Por. Rozporządzenie Rady nr 2603/69 z 20 grudnia 1969 r. (Dz.Urz. WE L 324/69), zmodyfikowane Rozporządzeniem Rady nr 3918/91 z 19 grudnia 1991 r. (Dz.Urz. WE L 372/91).

${ }^{10} \mathrm{~W}$ uzasadnionych przypadkach Komisja może je wprowadzić sama, z własnej inicjatywy lub na wniosek państw członkowskich, notyfikując te środki Radzie i państwom członkowskim. Również kraje członkowskie mogą postąpić tak samo, tyle że na czas przejściowy (do momentu podjęcia decyzji przez Komisję lub Radę) i pod warunkiem notyfikowania tej decyzji Komisji.

${ }^{11}$ Warto zauważyć, że w porozumieniu ustanawiającym WTO Wspólnoty Europejskie zostały wymienione jako członek pierwotny tej organizacji, co oznaczało formalnoprawne zaakceptowanie faktu, iż Wspólnota reprezentuje interesy swych państw członkowskich. Z kolei na forum OECD której członkami są wszystkie państwa członkowskie UE-15, a spośród nowych członków: Czechy, Węgry, Polska, Słowacja, Słowenia i Estonia - Komisja Europejska również bierze udział w pracach tej organizacji.

${ }^{12}$ Rozporządzenie Rady z 22 grudnia 1994 r. 3286/94; Rozporządzenie w sprawie przeszkód w handlu (Trade Barriers Regulation - TBR), Official Journal L 349 z 31.12.1994 r. 
pejskim na rynkach państw trzecich oraz do egzekwowania praw wynikających z porozumień zawartych w ramach Światowej Organizacji Handlu (WTO). Komisja Europejska może podejmować te działania nie tylko na wniosek państw członkowskich, ale również na podstawie skargi przedsiębiorstw i stowarzyszeń przedsiębiorców, jeśli uznają, że utrudnienia na obcych rynkach naruszają międzynarodowe zasady handlowe.

W odróżnieniu od instrumentów traktatowych narzędzia wspierania eksportu o charakterze ekonomiczno-finansowym - z wyjątkiem subsydiów w eksporcie rolnym stosowanych $\mathrm{w}$ ramach wspólnej polityki rolnej - pozostają $\mathrm{w}$ gestii państw członkowskich. Autonomia członków UE, jeżeli chodzi o stosowanie tych narzędzi, jest jednak ograniczona licznymi uregulowaniami wspólnotowymi określającymi zasady ich stosowania. Regulacje wspólnotowe odnoszące się do instrumentów finansowego wspierania eksportu są przy tym z jednej strony konsekwencją zobowiązań UE podjętych na forum międzynarodowym (w tym w szczególności zobowiązań na forum WTO oraz OECD), z drugiej zaś wynikają one z realizacji programów wspólnotowych, m.in. wspólnej polityki rolnej oraz polityki ochrony konkurencji.

W obszarze wsparcia kredytów eksportowych przez kraje członkowskie UE w pełni obowiązują zasady przewidziane przez Konsensus OECD, który został inkorporowany do prawa unijnego decyzją Rady już w 1978 r. ${ }^{13}$ Ponadto od 1 kwietnia 1999 r. obowiązuje Dyrektywa Rady UE w sprawie harmonizacji głównych postanowień dotyczących ubezpieczenia kredytu eksportowego przy transakcjach objętych ubezpieczeniem średnio- i długoterminowym ${ }^{14}$. Wprowadziła ona ujednolicenie wielu instrumentów tej formy wsparcia, m.in. określone zostały jednolite warunki udzielania gwarancji i kredytów dla dostawcy oraz kredytów dla nabywcy, zakres pokrycia ryzyka przez ubezpieczyciela, zasady ustalania składek ubezpieczeniowych, interpretacja ryzyka handlowego i niehandlowego itp. Organem odpowiadającym za kontrolę i przeciwdziałanie pośredniemu dumpingowi kredytowo-ubezpieczeniowemu we Wspólnocie jest Komisja Europejska.

Zgodnie z Porozumieniem w sprawie subsydiów i środków wyrównawczych Światowej Organizacji Handlu, zaaprobowanej przez Unię Europejską decyzją Rady w 1994 r. ${ }^{15}$, stosowanie subwencji eksportowych przez kraje członkowskie jest zakazane. Wyjątkiem są subsydia udzielane w eksporcie artykułów rolnych, które są stosowane w UE w formie refundacji wywozowych (export refunds). Refundacja wywozowa stanowi formę dopłaty pokrywającej - częściowo lub

${ }^{13}$ Decyzja Rady z dnia 4 kwietnia 1978 r., Official Journal L 98 z 11.04.1978 r.

${ }^{14}$ Dyrektywa Rady UE z 7 maja 1998 r., nr 98/29/EC, Official Journal L 148 z 19.05.1998 r.

15 Decyzja Rady UE z dnia 22 grudnia 1994 r., nr 94/800/EC, Official Journal L 336 z 23.12.1994 r. 
całkowicie - różnicę między poziomem cen na rynkach światowych i na rynku wewnętrznym UE. Zasady stosowania refundacji określają szczegółowo przepisy wspólnej polityki handlowej, wspólnej polityki rolnej oraz przepisy sektorowe. Najważniejsze z nich są następujące:

- wykaz towarów rolno-spożywczych objętych refundacjami zawiera załącznik I do traktatu amsterdamskiego ${ }^{16}$;

- wysokość obowiązujących stawek refundacji ustala Komisja Europejska i są one publikowane w Dzienniku Urzędowym UE;

- poziom stosowanych refundacji jest ustalany na określony czas i obowiązuje on eksporterów we wszystkich państwach członkowskich;

- niekiedy wysokość refundacji jest zróżnicowana w zależności od kierunku wywozu;

- refundacje pochodzą z budżetu UE i są wypłacane w poszczególnych państwach członkowskich przez krajowe agencje płatnicze.

Podobnie jak instrumenty ekonomiczno-finansowe, również narzędzia wspierania eksportu o charakterze informacyjno-promocyjnym pozostają głównie w gestii poszczególnych krajów członkowskich, jakkolwiek na poziomie Wspólnoty również są podejmowane działania w tym obszarze. Przykładem takich działań było np. utworzenie bazy danych, w której zbierane są informacje o rynkach krajów trzecich i barierach dostępu do nich. Wsparcie działań firm unijnych na rynkach pozaeuropejskich jest również prowadzone przez różne programy wspólnotowe, m.in. kierowane do małych i średnich przedsiębiorstw (np. jak Al.-Invest, ProInvest, EU Gateway Programme, The Executive Training Programme, TASBI), w ramach których finansowane są spotkania biznesowe, organizacja misji handlowych, targów, akcji promocyjnych, szkolenia o funkcjonowaniu zagranicznych rynków itp.

Wspieranie eksportu przez kraje członkowskie, w tym w szczególności wsparcie promocyjne, musi być zgodne z zasadami udzielania pomocy publicznej w UE, która - zgodnie z art. 87 TWE - jest, ogólnie rzecz biorąc, zakazana ${ }^{17}$. Za zgodne ze wspólnym rynkiem są uznawane pewne kategorie pomocy, określane w rozporządzeniach $\mathrm{KE}^{18}$, które są objęte wyłączeniami grupowymi, oraz pomoc

${ }^{16}$ Oprócz towarów zawartych w załączniku refundacje są również wypłacane w eksporcie towarów, które nie są objęte wspólną polityką rolną, tzw. non-anex I (jak np. czekolada, ciastka, lody), dla których ustalono odrębne regulacje handlowe [Hajdukiewicz 2008, s. 99 i nast.].

${ }^{17}$ Chodzi tu o pomoc pochodzącą ze środków publicznych, o charakterze selektywnym, która zakłóca konkurencję lub grozi jej zakłóceniem i ma wpływ na wymianę handlową między krajami członkowskimi.

${ }^{18}$ Kwestię przyznawania pomocy w ramach wyłączeń grupowych reguluje Rozporządzenie Komisji nr 800/2008 z dnia 6 sierpnia 2008 r., które za dopuszczalną uznaje: pomoc regionalną, pomoc inwestycyjną i na zatrudnienie dla MSP, pomoc na zakładanie przedsiębiorstw 
de minimis ${ }^{19}$. Działania państw członkowskich UE na rzecz promocji i wspierania eksportu są obecnie oparte główne na zasadzie de minimis.

\section{Podsumowanie}

Członkostwo Polski w organizacjach międzynarodowych, a także jej akcesja do Unii Europejskiej mają fundamentalne znaczenie dla kształtu polskiej polityki proeksportowej oraz dostępnych jej narzędzi. Przystępując do WTO, OECD, a następnie UE, uzyskano wprawdzie istotną poprawę warunków dostępu do rynków zagranicznych dla eksporterów, z drugiej jednak strony Polska zobowiązała się do przestrzegania licznych zasad wypracowanych na forum tych organizacji dotyczących dopuszczalnych form wspierania eksportu. W praktyce oznaczało to konieczność rezygnacji ze stosowania niektórych narzędzi polityki proeksportowej bądź też objęcie ich rygorystycznymi ograniczeniami. Dodatkowo przyjęcie przez Polskę jednolitych zasad wspólnej polityki handlowej spowodowało znaczącą utratę autonomii kraju w zakresie kształtowania jego polityki i systemu wspierania eksportu.

Istniejące ograniczenia, o czym nie można zapominać, dotyczą w takim samym zakresie innych członków omawianych organizacji, a ich nadrzędnym celem jest harmonijny rozwój handlu dzięki usuwaniu zaburzeń swobodnej, wolnej konkurencji na rynku międzynarodowym. Zmniejszenie dostępnego instrumentarium polityki proeksportowej rodzi jednak konieczność doskonalenia dopuszczalnych narzędzi wspierania eksportu i poprawy efektywności ich wykorzystania, a także poszukiwania i wdrażania nowych rozwiązań stymulujących rozwój polskiego eksportu.

\section{Literatura}

Agreement on Subsidies and Countervailing Measures, www.wto.org/english/docs_e/ legal_e (data dostępu: 12.11.2013).

przez kobiety, pomoc na ochronę środowiska, pomoc na usługi doradcze dla MSP i udział MSP w targach, pomoc w formie kapitału podwyższonego ryzyka, pomoc na działalność badawczą, rozwojową i innowacyjną, pomoc szkoleniową, pomoc dla pracowników znajdujących się w szczególnie niekorzystnej sytuacji lub niepełnosprawnych.

${ }^{19}$ Pomoc de minimis stanowi szczególną kategorię wsparcia udzielanego przez państwo, gdyż uznaje się, że ze względu na swą małą wartość nie powoduje ona zakłócenia konkurencji w wymiarze unijnym. Zasady jej udzielania określa Rozporządzenie Komisji nr 1998/2006 z dnia 15 grudnia 2006 r. (Official Journal L 379 z 28.12.2006 r.), zgodnie z którym łączna wartość pomocy de minimis dla jednego beneficjenta nie może przekroczyć równowartości 200 tys. euro brutto w okresie trzech lat kalendarzowych, a w przypadku podmiotu prowadzącego działalność gospodarczą w sektorze transportu drogowego - 100 tys. euro. 
Barcz J., Kawecka-Wyrzykowska E., Michałowska-Gorywoda K. [2007], Integracja europejska, Wolters Kluwer, Warszawa.

Bednarczyk T.H. [2000], Instrumenty wspierania eksportu. Kredyty i ubezpieczenia, Wydawnictwo Naukowe PWN, Warszawa.

Bhagwati J. [2003], Wolny handel dziś, CeDeWu, Warszawa.

Bożyk P., Misala J., Puławski M. [1998], Międzynarodowe stosunki ekonomiczne, PWE, Warszawa.

Domiter M. [2008], Eksport w doktrynie i polityce gospodarczej na tle procesów liberalizacyjnych $i$ integracyjnych, Wydawnictwo AE we Wrocławiu, Monografie i Opracowania, nr 185, Wrocław.

Gorynia M. [1996], Międzynarodowa konkurencyjność polskiej gospodarki a polityka ekonomiczna, ,Ekonomista”, nr 3.

Hajdukiewicz A. [2012], Liberalizacja handlu artykułami rolno-spożywczymi na forum rundy Doha WTO - stan i perspektywy negocjacji, „Zeszyty Naukowe Uniwersytetu Ekonomicznego w Krakowie", nr 888.

Hajdukiewicz A. [2009], Subsydiowanie rolnictwa jako przedmiot wielostronnych uregulowań i kontrowersji na forum GATT/WTO, ,Zeszyty Naukowe Uniwersytetu Ekonomicznego w Krakowie", nr 794.

Hajdukiewicz A. [2008], Refundacje wywozowe jako forma bezpośrednich subsydiów eksportowych w Unii Europejskiej $i$ ich stosowanie w polskim eksporcie towarów rolno-spożywczych, ,Zeszyty Naukowe Uniwersytetu Ekonomicznego w Krakowie”, nr 777.

Michalik A. [2009], Wpływ liberalizacji handlu na funkcjonowanie narzedzi polityki proeksportowej państwa (na przykładzie kredytów eksportowych), „Zeszyty Naukowe Uniwersytetu Ekonomicznego w Krakowie", nr 794.

Pierzchlewski W. [2011], Polityka państwa w zakresie wspierania aktywności małych i średnich przedsiębiorstw w handlu międzynarodowym Polski, Wydawnictwo UE we Wrocławiu, Wrocław.

Rębalski M. [2006], Polityka proeksportowa państwa w teorii handlu zagranicznego, „Zeszyty Naukowe Akademii Ekonomicznej w Krakowie”, nr 721.

Rosati D. [1990], Polityka proeksportowa, PWE, Warszawa.

Wziątek-Kubiak A. [1996], Kontrowersje wokół proeksportowej strategii rozwoju, Poltext, Warszawa.

\section{Support for Exports in the Light of Poland's International Obligations}

The systemic measures oriented towards stimulating Polish exports include treaty arrangements, financial, informational and promotional support. These instruments are governed by the rules and restrictions imposed by GATT/WTO, OECD and European Union. The objective of this article is to present these organisations's main regulations governing the support for exports and to analyse the consequences of implementing them for Poland's system for supporting exports.

Keywords: trade policy, export, trade liberalisation, World Trade Organization. 